\title{
Usulan Strategi Perawatan Mesin Breaker dan Mesin Hammermill di PT. P\&P Bangkinang
}

\author{
Wresni Anggraini ${ }^{1}$, Dita Febrilia Ramadani ${ }^{2}$ \\ 1,2 Jurusan Teknik Industri, Fakultas Sains dan Teknologi, UIN Sultan Syarif Kasim Riau \\ Jl. HR. Soebrantas No. 155 Simpang Baru, Panam, Pekanbaru, 28293 \\ E-mail: wresni_anggraini @ymail.com
}

\begin{abstract}
ABSTRAK
PT. P \& P Bangkinang merupakan sebuah perusahaan yang bergerak dalam pengolahan karet PT. P \& P Bangkinang merupakan sebuah perusahaan yang bergerak dalam pengolahan karet mentah menjadi barang setengah jadi (Crumb Rubber) yang diekspor keluar negeri. Perusahaan ini menghadapi permasalahan berupa downtime mesin yang menyebabkan tindakan perawatan komponen dengan total biaya sebesar Rp. 236.974.518,-/tahun. Tujuan penelitian yang dilakukan adalah menentukan strategi perawatan mesin breaker dan mesin hammermill yang menghasilkan biaya minimum dengan metode proyeksi biaya perawatan berdasarkan nilai MTTF dan MTTR. Hasil yang diperoleh dari perhitungan biaya perawatan adalah komponen yang menggunakan biaya perawatan secara corrective maintenance sebesar Rp. 84.787.237,/tahun. Sedangkan biaya perawatan secara preventive maintenance sebesar Rp. 29.644.961,-/tahun. Strategi yang tepat adalah strategi penggabungan antara Corrective Maintenance dan Preventive Maintenance dengan menghasilkan biaya sebesar Rp. 157.154.298,-/tahun lebih kecil dibandingkan dengan biaya kondisi eksisting perusahaan.
\end{abstract}

Kata kunci: Biaya Perawatan, MTTF, MTTR, Perawatan

\section{ABSTRACT}

PT. P \& P Bangkinang is a company specializing in the processing of raw rubber into semi-finished products (Crumb Rubber) have been exported out of the country. The company faces problems such as the one caused maintenance action component of machine downtime with a total cost of Rp. 236,974,518, - I year. The objective of the research is to determine the processing strategy and machine of the hammermill cutting machine that produces the minimum cost with the method of projection of maintenance costs as a function of the value of MTTF and MTTR. The results obtained from the calculation of the cost of care is a component that uses the corrective maintenance maintenance costs Rp. 84,787,237, - / year. While the cost of care in $R p$ preventive maintenance. 29.644.961, - / year. The right strategy is the strategy of merging Corrective Maintenance and Preventive Maintenance by generating Rp costs 157154 298, - / year less than the cost of the current state of the company.

Keywords: Maintenance, Maintenance Cost, MTTF, MTTR

\section{Pendahuluan}

Mesin-mesin produksi merupakan faktor produksi yang berfungsi mengkonversi bahan baku menjadi bahan setengah jadi atau bahan jadi. Mesin merupakan pesawat pengubah energi yang beroperasi berdasarkan prinsip-prinsip logis, rasional dan matematis. Kebutuhan produktivitas yang lebih tinggi serta meningkatnya keluaran mesin pada tahun-tahun terakhir ini telah mempercepat perkembangan otomatisasi. Hal ini pada gilirannya memperbesar kebutuhan akan fungsi pemeliharaan (maintenance) mesin-mesin tersebut, selain karena mesin-mesin tersebut cenderung terus mengalami kelusuhan sehingga diperlukan reparasi atau perbaikan (Iswanto, 2008).

Terhentinya suatu proses di lantai produksi seringkali disebabkan adanya masalah dalam fasilitas produksi, misalnya kerusakan-kerusakan mesin yang tidak terdeteksi selama proses produksi 
berlangsung yang mengakibatkan terhentinya proses. Hal ini tentunya sangat merugikan pihak perusahaan karena selain dapat menurunkan tingkat kepercayaan konsumen juga mengakibatkan adanya biaya-biaya yang harus dikeluarkan akibat kerusakan itu (Octavia, 2001).

PT. P \& P Bangkinang merupakan sebuah perusahaan yang bergerak dalam pengolahan karet mentah menjadi barang setengah jadi (Crumb Rubber) yang diekspor keluar negeri. Jenis produk yang dihasilkan yaitu Crumb Rubber SIR-10 (Standard Indonesia Rubber) dan SIR-20. Perbedaan dari dua jenis ini adalah SIR-10 menggunakan bahan baku yaitu $85 \%$ bokar (bongkahan karet) A dan 15\% bokar B, sedangkan untuk jenis SIR-20 yang memiliki kualitas dibawah SIR-10 yaitu dengan komposisi bokar A sebanyak $40 \%$ dan bokar B sebanyak $60 \%$.

Pada saat dilakukan penelitian terdahulu (Aditia, 2016) pada PT. P \& P Bangkinang, mesin yang sering mengalami kerusakan adalah mesin Breaker dan mesin Hamermill. Rusaknya mesin akan menghentikan aktivitas produksi selama beberapa saat, dan berdampak pada menganggurnya pekerja dan mesin (idle time) sehingga perusahaan harus mengeluarkan biaya untuk mengatasinya. Hal ini jelas merugikan perusahaan, mengingat target produksi yang harus dicapai oleh perusahaan. Berikut ini merupakan data kehilangan waktu produksi (downtime) mesin breaker dan mesin hammermill pada PT P \& P Bangkinang:

Tabel 1. Data Downtime Mesin Breaker dan Mesin Hammermill Tahun 2015

\begin{tabular}{|c|c|c|c|c|c|c|}
\hline \multirow{2}{*}{ Bln } & \multirow{2}{*}{$\begin{array}{c}\text { Hari } \\
\text { Kerja } \\
\text { per } \\
\text { Bulan }\end{array}$} & \multirow{2}{*}{$\begin{array}{c}\text { Jam } \\
\text { Kerja } \\
\text { per } \\
\text { Hari }\end{array}$} & \multirow{2}{*}{$\begin{array}{c}\text { Machine } \\
\text { Break } \\
\text { (Jam) }\end{array}$} & \multicolumn{2}{|c|}{$\begin{array}{c}\text { Planned } \\
\text { Downtime }\end{array}$} & \multirow{2}{*}{$\begin{array}{c}\text { Down } \\
\text { time } \\
\text { (Jam) }\end{array}$} \\
\hline & & & & $\begin{array}{c}\text { Warm } \\
\text { up } \\
(\mathrm{Jam})\end{array}$ & $\begin{array}{c}\text { Setup } \\
\text { Time } \\
\text { (Jam) }\end{array}$ & \\
\hline Jan & 22 & 8 & 10,65 & 8,91 & 6,83 & 26,39 \\
\hline Feb & 19 & 8 & 4,95 & 7,92 & 6,22 & 19,09 \\
\hline Mar & 22 & 8 & 7,89 & 8,58 & 6,92 & 23,39 \\
\hline Apr & 20 & 8 & 6,81 & 8,58 & 6,63 & 22,02 \\
\hline Mei & 19 & 8 & 3,28 & 7,90 & 5,72 & 16,90 \\
\hline Juni & 22 & 8 & 8,02 & 8,58 & 7,73 & 24,33 \\
\hline Juli & 23 & 8 & 11,98 & 8,91 & 6,79 & 27,68 \\
\hline Agust & 20 & 8 & 5,04 & 8,58 & 6,58 & 20,20 \\
\hline Sept & 22 & 8 & 6,47 & 8,58 & 7,48 & 22,53 \\
\hline Okt & 22 & 8 & 7,63 & 8,91 & 6,84 & 23,38 \\
\hline Nov & 21 & 8 & 10,87 & 8,58 & 7,61 & 27,06 \\
\hline Des & 21 & 8 & 10,64 & 8,91 & 7,23 & 26,78 \\
\hline Total & 253 & 96 & 94,23 & 102,94 & 82,58 & $\begin{array}{c}279,7 \\
5\end{array}$ \\
\hline
\end{tabular}

Sumber: Data PT. P \& P Bangkinang (2015)
Kerusakan mesin atau peralatan (Equipment Failure Breakdowns) mengakibatkan berkurangnya volume produksi. Pada saat terjadi kerusakan, mengakibatkan berkurangnya output yang dihasilkan perusahaan karena mesin tidak berproduksi, sehingga target produksi perusahaan tidak tercapai dan waktu menganggur karyawan menjadi lebih banyak berujung pada biaya yang harus dikeluarkan perusahaan menjadi meningkat.

Tindakan perawatan pada mesin Breaker dan Hamermill harus dilakukan agar menjaga kondisi mesin dan komponen dalam keadaan baik dan dapat beroperasi sesuai dengan fungsinya sehingga target produksi dapat dicapai perusahaan seoptimal mungkin. Berikut ini merupakan data produksi dan target perusahaan di PT. P \& P Bangkinang:

Tabel 2. Produksi Crumb Rubber SIR-10 dan SIR-20 Tahun 2015

\begin{tabular}{|c|c|c|c|c|c|}
\hline \multirow{2}{*}{ BIn } & \multicolumn{2}{|c|}{$\begin{array}{c}\text { Produksi Crumb } \\
\text { Rubber (Kg) }\end{array}$} & \multirow{2}{*}{ Total } \\
\cline { 2 - 3 } Produksi & $\begin{array}{c}\text { Target } \\
\text { Perus per } \\
\text { Bulan }\end{array}$ & $\begin{array}{c}\text { Ketercapaian } \\
\text { Target } \\
\text { Produksi }\end{array}$ \\
\hline Jan & 60.120 & 1.022 .970 & 1.082 .970 & 1.200 .000 & $(-) 117.030$ \\
\hline Feb & 2.520 & 950.470 & 952.990 & 1.200 .000 & $(-) 247.010$ \\
\hline Mar & 115.460 & 1.215 .440 & 1.330 .900 & 1.500 .000 & $(-) 169.100$ \\
\hline Apr & 64.260 & 1.127 .168 & 1.191 .428 & 1.500 .000 & $(-) 308.572$ \\
\hline Mei & 189.000 & 1.166 .180 & 1.355 .180 & 1.500 .000 & $(-) 144.820$ \\
\hline Juni & 120.960 & 1.065 .330 & 1.186 .290 & 1.400 .000 & $(-) 213.710$ \\
\hline
\end{tabular}

Sumber: Data PT. P \& P Bangkinang (2015)

Tabel 3. Produksi Crumb Rubber SIR-10 dan SIR-20 Tahun 2015

\begin{tabular}{|c|c|c|c|c|c|}
\hline \multirow{2}{*}{ BIn } & \multicolumn{2}{|c|}{$\begin{array}{c}\text { Produksi Crumb } \\
\text { Rubber }(\text { Kg) }\end{array}$} & \multirow{2}{*}{$\begin{array}{c}\text { Total } \\
\text { Produksi }\end{array}$} & $\begin{array}{c}\text { Target } \\
\text { Perusahaan } \\
\text { per Bulan }\end{array}$ & $\begin{array}{c}\text { Ketercapaian } \\
\text { Target } \\
\text { Produksi }\end{array}$ \\
\cline { 2 - 3 } Juli & 49.140 & 1.091 .630 & 1.140 .770 & 1.400 .000 & $(-) 259.230$ \\
\hline Agust & 55.440 & 895.230 & 950.670 & 1.200 .000 & $(-) 249.330$ \\
\hline Sept & 100.800 & 912.120 & 1.012 .920 & 1.200 .000 & $(-) 187.080$ \\
\hline Okt & 138.600 & 1.258 .740 & 1.397 .340 & 1.500 .000 & $(-) 102.660$ \\
\hline Nov & 2.520 & 969.750 & 972.270 & 1.200 .000 & $(-) 227.730$ \\
\hline Des & 13.480 & 955.330 & 968.810 & 1.200 .000 & $(-) 231.190$ \\
\hline Total & 852.180 & 12.690 .358 & 13.542 .538 & 16.000 .000 & $(-) 2.457 .462$ \\
\hline $\begin{array}{c}\text { Prdkt } \\
\text { vitas }\end{array}$ & & \multicolumn{5}{|c}{$86,33 \%$} & \\
\hline
\end{tabular}

Sumber: Data PT. P \& P Bangkinang (2015)

Dari Tabel 3 dapat dilihat target produksi dari bulan Januari sampai Desember masih belum mencapai target yang diinginkan perusahaan. Maka dari itu, untuk mempertahankan maupun meningkatkan hasil produksinya, perusahaan harus melakukan perawatan mesin untuk menghindari kerusakan dini pada komponen. Berdasarkan penelitian terdahulu (Aditia, 2016), berikut merupakan skenario perawatan untuk masing- 
masing komponen yang sering mengalami kerusakan:

Tabel 4. Skenario Perawatan Untuk Masing-Masing Komponen Kritis

\begin{tabular}{|c|c|c|c|c|}
\hline \multirow{2}{*}{ Komponen } & \multicolumn{2}{|c|}{$\begin{array}{c}\text { Kondisi Aktual } \\
\text { (Corrective } \\
\text { Maintenance) }\end{array}$} & \multicolumn{2}{c|}{$\begin{array}{c}\text { Kondisi Usulan } \\
\text { (Preventive } \\
\text { Maintenance) }\end{array}$} \\
\cline { 2 - 5 } & MTTF & Reliability & MTTF & Reliability \\
\hline Gear Kecil & 556 & $63,27 \%$ & $\begin{array}{c}492,62 \\
\text { Jam }\end{array}$ & $43 \%$ \\
& Jam & & 727 & $68,04 \%$ \\
\hline Kelahar & 727 & $20,85 \%$ & Jam & $58,50 \%$ \\
& Jam & & 398 & $50,57 \%$ \\
Bearing & 398 & 509 & Jam & \\
\hline Kelahar & 459 & $52,19 \%$ & 406,67 & $62,83 \%$ \\
Conveyor & Jam & & Jam & \\
\hline
\end{tabular}

Sumber: Pengolahan Data (2016)

Pada kondisi aktual, nilai MTTF dari komponen kritis mesin diganti ketika mengalami dan untuk kondisi usulan, komponen kritis diganti sesuai waktu berdasarkan nilai MTTF dari komponen kritis. Dapat dilihat dari nilai MTTF komponen kritis mesin diatas bahwa kerusakan komponen rata-rata terjadi pada saat komponen mesin sudah lama digunakan dan diperlukan pergantian komponen.

Ini dibuktikan dari hasil persentase reliabilitas masing-masing komponen kritis diatas, dapat dilihat kehandalan dari komponen Gear kecil pada kondisi aktual sebesar 63,27\% hal tersebut menandakan bahwa tingkat kehandalan komponen sudah mulai menurun, sementara, pada kondisi usulan tingkat kehandalan komponen sebesar $43 \%$. Dapat disimpulkan bahwa pergantian komponen Gear kecil akan lebih optimal jika dilakukan pada saat kondisi aktual (Corrective Maintenance) karena memiliki tingkat kehandalan tertinggi pada saat dilakukan pergantian komponen. Berbeda dengan perbandingan tingkat kehandalan kelahar, Bearing dan Kelahar Conveyor pada kondisi aktual dan kondisi usulan yang akan lebih optimal jika dilakukan pergantian komponen pada saat kondisi usulan (Preventive Maintenance).

Tindakan pergantian komponen dilakukan pada dua kondisi yaitu kondisi pergantian ketika terjadinya kerusakan dan pergantian sebelum timbul kerusakan. Tindakan pergantian komponen ini tentu menimbulkan biaya bagi perusahaan, yaitu biaya pergantian ketika terjadi kerusakan dan biaya pergantian sebelum timbulnya kerusakan.

Berdasarkan latar belakang diatas, pada saat dilakukan Preventive Maintenance dengan jadwal yang telah ditentukan, maka dapat disimpulkan, komponen Gear kecil akan dilakukan pergantian komponen secara langsung (Corrective Maintenance) dan untuk komponen kelahar, Bearing dan Kelahar Conveyor akan dilakukan pergantian komponen pada waktu yang ditentukan
(Preventive Maintenance). Pergantian komponenkomponen ini akan berhubungan dengan biaya yang harus dikeluarkan perusahaan, dengan adanya perhitungan biaya perawatan, maka dapat diketahui jumlah biaya yang dikeluarkan untuk perawatan. Oleh karena itu, penulis melakukan proyeksi biaya perawatan untuk menentukan perawatan mesin Breaker dan Hammermill yang tepat, efektif dan ekonomis, dengan membandingkan biaya Corrective Maintenance dengan Preventive Maintenance berdasarkan pada skenario perawatan pada setiap komponen.

\section{Metode Penelitian}

Metodologi penelitian merupakan tahapantahapan yang dilalui peneliti mulai dari pengumpulan data sampai dengan penarikan kesimpulan yang membentuk sebuah alur yang sistematis. Tahapan penelitian dipaparkan pada flowchart dibawah ini:

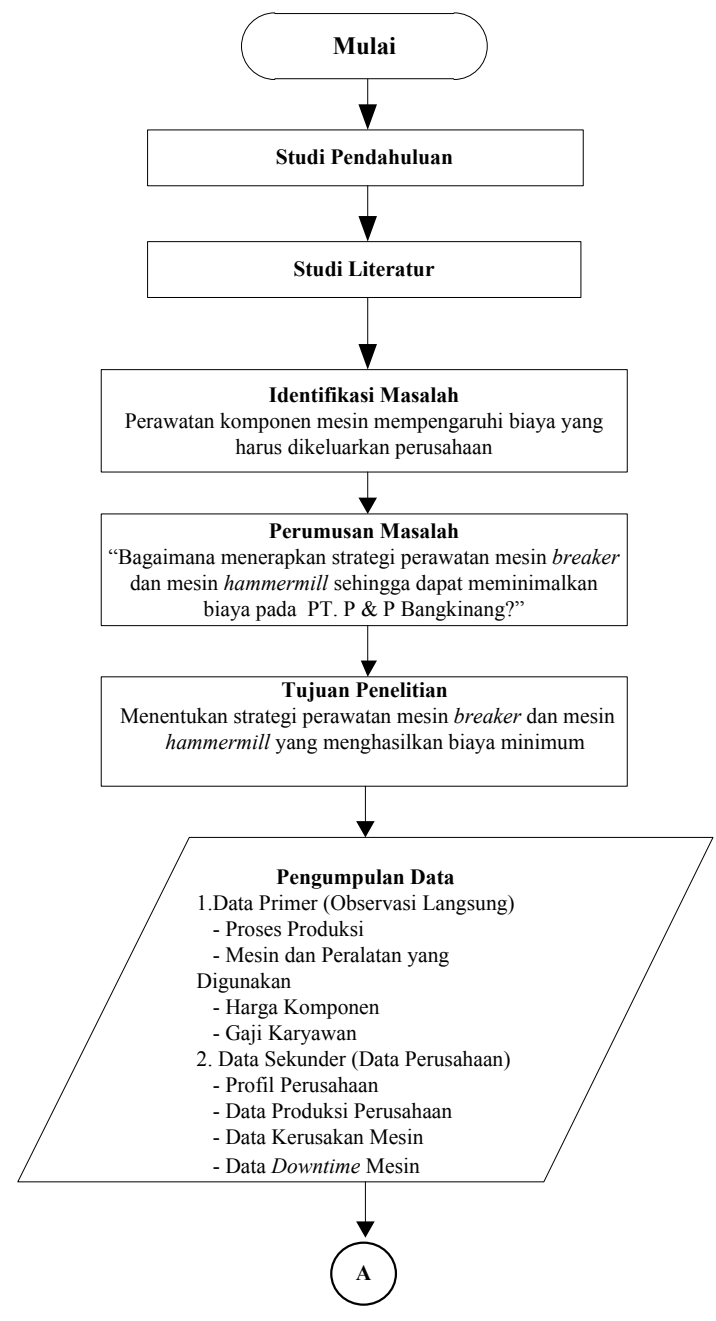

Gambar 1. Metodologi Penelitian 


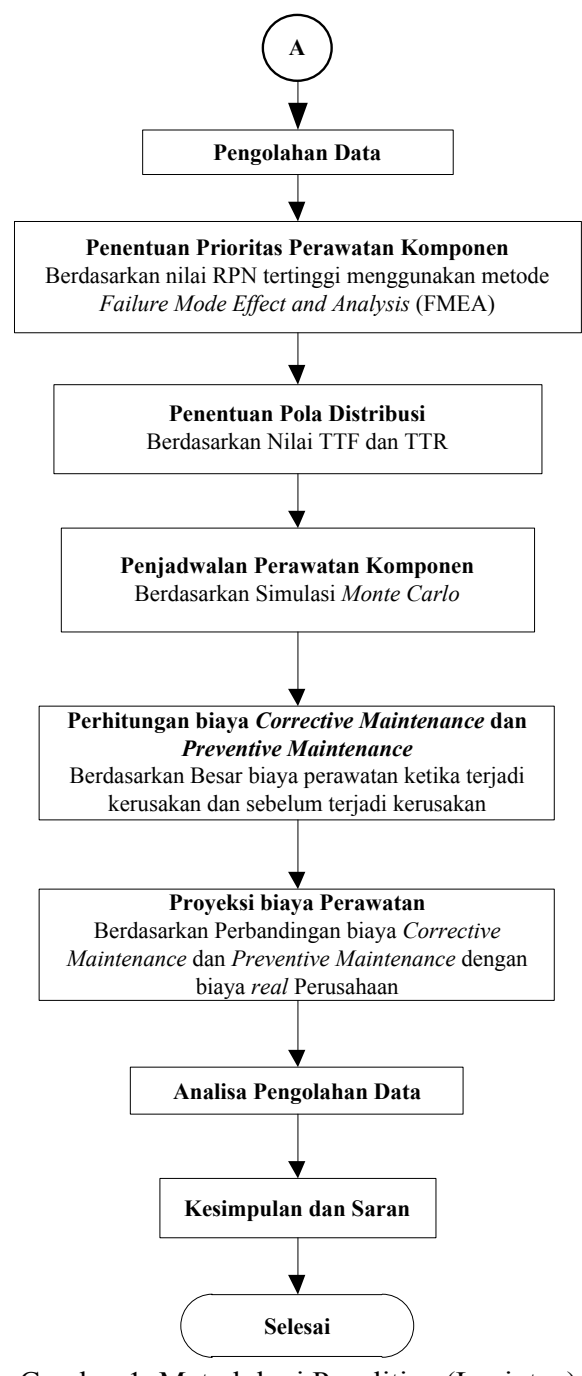

Gambar 1. Metodologi Penelitian (Lanjutan)

\section{Hasil dan Pembahasan}

\section{Penentuan Prioritas Perawatan Komponen}

Penentuan prioritas perawatan komponen dengan menggunakan FMEA (Failure Mode \& Effect Analysis) berdasarkan hasil nilai RPN tertinggi dengan mengidentifikasi model-model kegagalan, menentukan akibat dari kegagalan dan menentukan tindakan yang dilakukan untuk mengatasi kegagalan tersebut

\section{Penentuan Pola Distribusi}

Pengujian distribusi dan penentuan parameter menggunakan data TTF dan TTR dari komponen mesin. Time to Failure (TTF) merupakan interval waktu antar kerusakan yang dihitung dari selisih antara waktu mesin atau komponen selesai diperbaiki sampai dengan waktu kerusakan mesin atau komponen berikutnya. Sedangkan Time to Repair (TTR) adalah waktu yang diperlukan untuk melakukan perbaikan terhadap mesin atau komponen yang mengalami masalah atau kerusakan sampai mesin atau komponen tersebut dapat beroperasi dengan baik.

Tabel 5. Rekapitulasi Uji Distribusi dan Parameter TTF

\begin{tabular}{|c|c|c|}
\hline No & Komponen & Pola Distribusi \\
\hline 1 & Pisau Rotor & Lognormal \\
\hline 2 & Pisau Duduk & Weibull \\
\hline 3 & Gear Kecil & Lognormal \\
\hline 4 & Kincir Pendayung & Weibull \\
\hline 5 & Rantai Conveyor & Weibull \\
\hline 6 & Kelahar & Lognormal \\
\hline 7 & Gigi Besar & Weibull \\
\hline 8 & Corong Mesin & Lognormal \\
\hline 9 & Baut Kap & Normal \\
\hline 10 & Conveyor Mesin & Lognormal \\
\hline 11 & Pisau Rotor & Lognormal \\
\hline 12 & Pisau Duduk & Weibull \\
\hline 13 & Dinamo Pendayung & Weibull \\
\hline 14 & Rantai Pendayung & Weibull \\
\hline 15 & Kelahar Conveyor & Exponential \\
\hline 16 & Pompa Air Aorot & Weibull \\
\hline 17 & Hammermill Inti & Lognormal \\
\hline 18 & Rantai Conveyor & Normal \\
\hline 19 & Bearing & Weibull \\
\hline 20 & $\begin{array}{l}\text { Conveyor } \\
\text { Hammermill }\end{array}$ & Weibull \\
\hline
\end{tabular}

Sumber: Pengolahan Data (2017)

Tabel 6. Rekapitulasi Uji Distribusi dan Parameter TTR

\begin{tabular}{|c|l|c|}
\hline No & Kerusakan Mesin & Pola Distribusi \\
\hline 1 & Pisau Rotor & Weibull \\
\hline 2 & Pisau Duduk & Normal \\
\hline 3 & Gear Kecil & Weibull \\
\hline 4 & Kincir Pendayung & Normal \\
\hline
\end{tabular}

Sumber: Pengolahan Data (2017) 
Tabel 6. Rekapitulasi Uji Distribusi dan Parameter TTR (lanjutan)

\begin{tabular}{|c|c|c|}
\hline No & Kerusakan Mesin & Pola Distribusi \\
\hline 5 & Rantai Conveyor & Lognormal \\
\hline 6 & Kelahar & Normal \\
\hline 7 & Gigi Besar & Weibull \\
\hline 8 & Corong Mesin & Weibull \\
\hline 9 & Baut Kap & Normal \\
\hline 10 & Conveyor Mesin & Weibull \\
\hline 11 & Pisau Rotor & Weibull \\
\hline 12 & Pisau Duduk & Normal \\
\hline 13 & Dinamo Pendayung & Normal \\
\hline 14 & Rantai Pendayung & Weibull \\
\hline 15 & Kelahar Conveyor & Weibull \\
\hline 16 & Pompa Air Aorot & Normal \\
\hline 17 & Hammermill Inti & Normal \\
\hline 18 & Rantai Conveyor & Normal \\
\hline 19 & Bearing & Normal \\
\hline 20 & $\begin{array}{l}\text { Conveyor } \\
\text { Hammermill }\end{array}$ & Weibull \\
\hline
\end{tabular}

Sumber: Pengolahan Data (2017)

Dari tabel diatas dapat diketahui rekapitulasi distribusi dari data TTR komponen mesin dan juga parameternya dimana parameter tersebut dibutuhkan dalam membangkitan bilangan acak.

\section{Penjadwalan Perawatan Komponen}

Simulasi Monte Carlo dikenal juga dengan istilah Sampling Simulation atau Monte Carlo Sampling Technique. Model simulasi Monte Carlo merupakan bentuk simulasi pobabilistik dimana solusi dari suatu masalah diberikan proses randomisasi (acak). Bilangan acak digunakan untuk menjelaskan kejadian acak setiap waktu dari variabel acak dan secara berurutan mengikuti perubahan-perubahan yang terjadi dalam proses simulasi.
Tabel 7. Rekapitulasi Total Perawatan dan Total Downtime

\begin{tabular}{|c|c|c|c|c|c|c|}
\hline \multirow{2}{*}{ Komponen } & \multicolumn{2}{|c|}{ Kondisi Awal } & \multicolumn{2}{|c|}{$\begin{array}{c}\text { Kondisi } \\
\text { Corrective }\end{array}$} & \multicolumn{2}{|c|}{$\begin{array}{c}\text { Kondisi } \\
\text { Preventive }\end{array}$} \\
\hline & Frek. & $\begin{array}{c}\text { Dt } \\
(\text { Jam) }\end{array}$ & Frek. & $\begin{array}{c}\text { Dt } \\
(\text { Jam })\end{array}$ & Frek. & $\begin{array}{c}\text { Dt } \\
\text { (Jam) }\end{array}$ \\
\hline Pisau Rotor & 37 & 47 & 12 & 19,54 & 5 & 7,65 \\
\hline $\begin{array}{l}\text { Pisau } \\
\text { Duduk }\end{array}$ & 23 & 29,5 & 9 & 10,99 & 3 & 2,84 \\
\hline Gear Kecil & 10 & 8,5 & 5 & 3,99 & 1 & 0,66 \\
\hline $\begin{array}{l}\text { Kincir } \\
\text { Pendayung }\end{array}$ & 4 & 5 & 1 & 0,36 & - & - \\
\hline $\begin{array}{l}\text { Rantai } \\
\text { Conveyor }\end{array}$ & 5 & 6 & 3 & 2,28 & 1 & 0,78 \\
\hline Kelahar & 8 & 10,5 & 5 & 5,36 & 1 & 1,20 \\
\hline Gigi Besar & 18 & 23,5 & 7 & 9,68 & 2 & 2,74 \\
\hline $\begin{array}{l}\text { Corong } \\
\text { Mesin }\end{array}$ & 19 & 22,5 & 1 & 0,98 & 2 & 2,53 \\
\hline Baut Kap & 4 & 5 & 1 & 1,02 & 1 & 1,50 \\
\hline $\begin{array}{l}\text { Conveyor } \\
\text { Mesin }\end{array}$ & 15 & 17,5 & 9 & 9,81 & 1 & 0,59 \\
\hline Pisau Rotor & 30 & 35 & 11 & 13,77 & 5 & 6,24 \\
\hline $\begin{array}{l}\text { Pisau } \\
\text { Duduk }\end{array}$ & 18 & 21 & 4 & 6,81 & 5 & 5,29 \\
\hline $\begin{array}{l}\text { Dinamo } \\
\text { Pendayung }\end{array}$ & 10 & 14 & 6 & 8,24 & 3 & 5,74 \\
\hline $\begin{array}{l}\text { Rantai } \\
\text { Pendayung }\end{array}$ & 18 & 23,5 & 14 & 20,71 & - & - \\
\hline $\begin{array}{l}\text { Kelahar } \\
\text { Conveyor }\end{array}$ & 11 & 15 & 5 & 9,39 & 2 & 4,08 \\
\hline $\begin{array}{l}\text { Pompa Air } \\
\text { Aorot }\end{array}$ & 8 & 7,5 & 9 & 9,27 & 7 & 8,20 \\
\hline $\begin{array}{l}\text { Hammermill } \\
\text { Inti }\end{array}$ & 14 & 17,5 & 2 & 2,32 & 2 & 2,32 \\
\hline $\begin{array}{l}\text { Rantai } \\
\text { Conveyor }\end{array}$ & 6 & 6 & 1 & 0,34 & 1 & 0,85 \\
\hline Bearing & 6 & 8 & 1 & 1,85 & 4 & 3,63 \\
\hline $\begin{array}{l}\text { Conveyor } \\
\text { Hammermill }\end{array}$ & 4 & 5 & 1 & 1,14 & 2 & 1,98 \\
\hline Total & 268 & 327,5 & 107 & 137,5 & 48 & 58,82 \\
\hline
\end{tabular}

Sumber: Pengolahan Data (2017)

\section{Perhitungan Total Biaya Perawatan}

1. Corong Mesin (Corrective Maintenance)

$$
\begin{aligned}
\mathrm{C}_{\mathrm{CM}} & =\mathrm{WH} \frac{M T T R+T_{\mathrm{T}}^{C}}{M T B F} \\
& =(1)(1.992) \frac{1,18+0,98}{72,36} \\
& =59,46
\end{aligned}
$$


2. Pisau Rotor (Preventive Maintenance)

$$
\begin{aligned}
\mathrm{C}_{\mathrm{PM}} & =\mathrm{WH} \frac{T_{\mathrm{R}}^{P}+T_{\mathrm{T}}^{P}}{T_{\mathrm{I}}^{P}} \\
& =(5)(1.992) \frac{1,27+1,53}{236,66} \\
& =117,83
\end{aligned}
$$

3. Pisau Duduk (Preventive Maintenance)

$$
\begin{aligned}
\mathrm{C}_{\mathrm{PM}} & =\mathrm{WH} \frac{T_{\mathrm{R}}^{P}+T_{\mathrm{T}}^{P}}{T_{\mathrm{I}}^{P}} \\
& =(200.000 \times 3)(1.992) \frac{1,28+0,94}{328,18} \\
& =\text { Rp.600.013,- }
\end{aligned}
$$

4. Pisau Rotor (Preventive Maintenance)

$$
\begin{aligned}
\mathrm{C}_{\mathrm{PM}} & =\mathrm{WH} \frac{T_{\mathrm{R}}^{P}+T_{\mathrm{T}}^{P}}{T_{\mathrm{I}}^{P}} \\
& =(5)(1.992) \frac{1,16+1,24}{261,20} \\
& =\text { Rp. 91,51,- }
\end{aligned}
$$

5. Pisau Duduk (Preventive Maintenance)

$$
\begin{aligned}
\mathrm{C}_{\mathrm{PM}} & =\mathrm{WH} \frac{T_{\mathrm{R}}^{P}+T_{\mathrm{T}}^{P}}{T_{\mathrm{I}}^{P}} \\
& =(200.000 \times 5)(1.992) \frac{1,16+1,08}{418,21} \\
& =\text { Rp. 10.669.472,- }
\end{aligned}
$$

\begin{tabular}{|c|c|c|}
\hline Komponen & $\begin{array}{l}\text { Kondisi } \\
\text { terpilih }\end{array}$ & $\begin{array}{c}\text { Biaya } \\
\text { perawatan }\end{array}$ \\
\hline Kincir Pendayung & $\begin{array}{l}\text { Corrective } \\
\text { Maintenance }\end{array}$ & Rp. 1,61.- \\
\hline Rantai Conveyor & $\begin{array}{l}\text { Preventive } \\
\text { Maintenance }\end{array}$ & Rp. 514.943,- \\
\hline Kelahar & $\begin{array}{l}\text { Preventive } \\
\text { Maintenance }\end{array}$ & Rp. 7,72.- \\
\hline Gigi Besar & $\begin{array}{l}\text { Preventive } \\
\text { Maintenance }\end{array}$ & $\begin{array}{c}\text { Rp. } \\
\text { 4.594.441,- }\end{array}$ \\
\hline Corong Mesin & $\begin{array}{l}\text { Corrective } \\
\text { Maintenance }\end{array}$ & Rp. 59,46.- \\
\hline Baut Kap & $\begin{array}{c}\text { Corrective } \\
\text { Maintenance }\end{array}$ & Rp. 180.180,- \\
\hline Conveyor Mesin & $\begin{array}{l}\text { Preventive } \\
\text { Maintenance }\end{array}$ & Rp. 6,88.- \\
\hline Pisau Rotor & $\begin{array}{l}\text { Preventive } \\
\text { Maintenance }\end{array}$ & Rp. 91,51.- \\
\hline Pisau Duduk & $\begin{array}{l}\text { Preventive } \\
\text { Maintenance }\end{array}$ & $\begin{array}{c}\text { Rp. } \\
\text { 10.669.472,- }\end{array}$ \\
\hline Dinamo Pendayung & $\begin{array}{l}\text { Preventive } \\
\text { Maintenance }\end{array}$ & Rp.8.321.882,- \\
\hline Rantai Pendayung & $\begin{array}{l}\text { Corrective } \\
\text { Maintenance }\end{array}$ & $\begin{array}{c}\text { Rp. } \\
83.676 .083,-\end{array}$ \\
\hline Kelahar Conveyor & $\begin{array}{l}\text { Corrective } \\
\text { Maintenance }\end{array}$ & Rp. 18,45.- \\
\hline Pompa Air Sorot & $\begin{array}{l}\text { Preventive } \\
\text { Maintenance }\end{array}$ & Rp. 83,75.- \\
\hline Hammermill Inti & $\begin{array}{l}\text { Preventive } \\
\text { Maintenance }\end{array}$ & $\begin{array}{c}\text { Rp. } \\
4.272 .813,-\end{array}$ \\
\hline Rantai Conveyor & $\begin{array}{l}\text { Corrective } \\
\text { Maintenance }\end{array}$ & Rp. 794.653,- \\
\hline Bearing & $\begin{array}{l}\text { Corrective } \\
\text { Maintenance }\end{array}$ & Rp. 136.260,- \\
\hline $\begin{array}{l}\text { Conveyor } \\
\text { Hammermill }\end{array}$ & $\begin{array}{l}\text { Corrective } \\
\text { Maintenance }\end{array}$ & Rp. 3,44.- \\
\hline
\end{tabular}

6. Dinamo (Preventive Maintenance)

$$
\begin{aligned}
\mathrm{C}_{\mathrm{PM}} & =\mathrm{WH} \frac{T_{\mathrm{R}}^{P}+T_{\mathrm{T}}^{P}}{T_{\mathrm{I}}^{P}} \\
& =(150.000 \times 3)(1.992) \frac{1,4+1,91}{356,54} \\
& =\operatorname{Rp} .8 .321 .882,-
\end{aligned}
$$

Tabel 8. Rekapitulasi Biaya Perawatan masing-masing komponen

\begin{tabular}{|l|l|l|}
\hline \multicolumn{1}{|c|}{ Komponen } & \multicolumn{1}{|c|}{$\begin{array}{c}\text { Kondisi } \\
\text { terpilih }\end{array}$} & \multicolumn{1}{c|}{$\begin{array}{c}\text { Biaya } \\
\text { perawatan }\end{array}$} \\
\hline Pisau Rotor & $\begin{array}{l}\text { Preventive } \\
\text { Maintenance }\end{array}$ & Rp. 117,83.- \\
\hline Pisau Duduk & $\begin{array}{l}\text { Preventive } \\
\text { Maintenance }\end{array}$ & Rp. 600.013,- \\
\hline Gear Kecil & $\begin{array}{l}\text { Preventive } \\
\text { Maintenance }\end{array}$ & Rp. 671.071,- \\
\hline
\end{tabular}

Sumber: Pengolahan Data (2017)
Tabel 9. Rekapitulasi Biaya Perawatan masing-masing komponen

Sumber: Pengolahan Data (2017)

$\mathrm{C}_{\mathrm{SPI}}=$ kebutuhan $/ \operatorname{tahun}(\mathrm{D})=48$ unit biaya pemesanan $(\mathrm{S})=$ Rp. 100.000 


$$
\text { biaya simpan } \begin{aligned}
(\mathrm{H}) & =60 \% \text { Rp. } 1.900 .000 \\
& =\text { Rp. } 1.140 .000
\end{aligned}
$$

$$
\begin{aligned}
& \text { harga persediaan }(\mathrm{C})=\mathrm{Rp} .1 .900 .000 \\
& \begin{array}{l}
\text { Qopt } \\
=\sqrt{\frac{2 \mathrm{DS}}{\mathrm{H}}} \\
=\sqrt{\frac{2(48)(100.000)}{1.140 .000}} \\
=\sqrt{8,42} \\
=2,90
\end{array}
\end{aligned}
$$$$
\mathrm{TIC}=\frac{\mathrm{D}}{\mathrm{Q}}(\mathrm{S})+\frac{\mathrm{Q}}{2}(\mathrm{H})
$$$$
=\frac{48}{2}(\mathrm{Rp} .100 .000)+\frac{3}{2}(\mathrm{Rp} .1 .140 .000)
$$$$
=\text { Rp.4.110.000 }
$$

TC

$$
\begin{aligned}
= & \frac{\mathrm{D}}{\mathrm{Q}}(\mathrm{S})+\frac{\mathrm{Q}}{2}(\mathrm{H})+\mathrm{DC} \\
= & \frac{48}{2}(\mathrm{Rp} \cdot 100.000)+\frac{3}{2}(\mathrm{Rp} \cdot 1.140 .000)+ \\
& (48)(\mathrm{Rp} .1900 .000) \\
= & \text { Rp. } 95.310 .000
\end{aligned}
$$$$
\mathrm{C}_{\mathrm{SPI}} \quad=\text { Rp. } 1.985 .625
$$$$
\mathrm{M}_{\mathrm{C}}=\mathrm{C}_{\mathrm{SPI}}+\mathrm{C}_{\mathrm{PM}}+\mathrm{C}_{\mathrm{CM}}
$$$$
\text { =Rp. } 42.058 .340+\text { Rp. 29.644.961 + }
$$$$
\text { Rp. 84.787.237 }
$$$$
\text { = Rp. 166.490.538,- }
$$

\section{Kesimpulan}

Berdasarkan hasil yang diperoleh dari pengolahan data dan berdasarkan penetapan tujuan yang ingin dicapai maka, dapat disimpulkan hasil penelitian yang telah dilakukan sebagai berikut:

Perhitungan biaya perawatan, komponen yang menggunakan biaya perawatan secara corrective maintenance adalah komponen corong mesin, kincir pendayung, baut kap, rantai hammermill, bearing dan conveyor memiliki total biaya perawatan secara corrective sebesar Rp. 84.787.237,-. Sedangkan perawatan secara preventive maintenance adalah pisau rotor breaker, pisau duduk breaker,gear kecil, rantai conveyor breaker, kelahar, gigi besar, conveyor breaker, pisau rotor hammermill, pisau duduk hammermill, dinamo pendayung, pompa air sorot dan hammermill inti memiliki total biaya perawatan secara preventive sebesar Rp. 29.644.961,-. Strategi yang tepat adalah strategi penggabungan antara Corrective Maintenance dan Preventive Maintenance dengan menghasilkan biaya sebesar
Rp. 157.154.298,- lebih kecil dibandingkan dengan biaya kondisi eksisting perusahaan yaitu sebesar Rp. 236.974.518,-

\section{Daftar Pustaka}

Aditia, Arfan. "Simulasi Monte Carlo dalam Penerapan Preventive Maintenance pada Mesin Breaker dan Mesin Hammermill (Studi Kasus: PT. P\&P Bangkinang)". Tugas Akhir - Jurusan Teknik Industri, UIN SUSKA RIAU, Pekanbaru, 2016

Andrilia, Dian., Tama, Ishardita Pambudi dan Rahman, Arif. "Strategi Perawatan pada Mesin Las Mig di Industri Karoseri Kendaraan Niaga dengan Simulasi Monte Carlo (Studi Kasus: PT. Adi Putro Wirasejati Malang)". Tugas Sarjana Jurusan Teknik Industri, Universitas Brawijaya, Malang, 2014

Ansori, Nachnul dan Mustajib. "Sistem Perawatan Terpadu (Integrated Maintenance System)", Yogyakarta: Graha Ilmu, 2013

Bustami, Bastian dan Nurlela. "Akutansi Biaya Jilid 3". Jakarta: Mitra Wacana Media. 2012

Cahyo, Winda Nur. "Pendekatan Simulasi monte carlo untuk pemilihan alternatif dengan decision tree pada nilai outcome yang probabilistik". Jurnal Teknoin Vol. 13, No, 2. Fakultas Teknologi Industri UII. 2008

Chrysler Corporation. "Potential Failure Mode and Effect Analysis (FMEA)". USA: Ford Motor Company. 1995

Darmo, Suryo. "Manajemen Perawatan dan Pemeliharaan Mesin Indsutri". Thesis Fakultas Teknik, Universitas Gadjah Mada, Yogyakarta, 2009

Ginting, Rosnani. "Sistem Produksi", Yogyakarta: Graha Ilmu, 2007

Hanif, Richma Yulinda, dkk. "Perbaikan Kualitas Produk Keraton Luxury di PT. X dengan menggunakan Metode Failure Mode and Effect Analysis (FMEA) dan Fault Tree Analysis (FTA)". Jurnal Online Institut Teknologi Nasional Vol. 3, No. 3. Teknik Industri ITENAS. 2015

Hasriyono, Miko. "Evaluasi Efektivitas Mesin dengan Penerapan Total Productive Maintenance (TPM) di PT. Hadi Baru". Tugas Sarjana - Departemen Teknik Industri, Universitas Sumatera Utara, Medan, 2009

Hutagaol, Henry Joy. "Penerapan Total Productive Maintenance (TPM) untuk meningkatkan efisiensi produksi dengan menggunakan metode overall equipment effectiveness di PT. Perkebunan Nusantara 3 Gunung 
Para". Tugas Sarjana - Departemen Teknik Industri, Universitas Sumatera Utara, Medan, 2009

Ireson, W.G dan Clyde F.Coombs. "Handbook of Reliability Engineering and Management". USA: McGraw-Hill. 1966

Iswanto, Apri Heri. "Manajemen Pemeliharaan Mesin-Mesin Produksi”. Karya Tulis Fakultas Pertanian USU. 2008

Kurniawan, Fajar. " Manajemen Perawatan Industri". Yogyakarta: Graha Ilmu. 2013

Kusuma, Hendra. "Perencanaan dan Pengendalian Produksi". Yogyakarta: Andi Offset. 2001

Yoliwan, Joni Ekarilsoni, dkk. "Analisis Kegagalan Operasi di Warehouse PT. VA dengan Failure Mode and Effect Analysis". Prosiding Seminar Nasional Teknik dan Manajemen Industri UAJY. 2011

Yuhelson, dkk. "Analisis Reliability dan Avaibility Mesin Pabrik Kelapa Sawit PT. Perkebunan Nusantara 3". Jurnal Dinamis Vol. 2, No. 6. Teknik Mesin USU. 2010

Octavia, Tanti, dkk. "Implementasi Total Productive Maintenance Non Jahit PT. Kerta Rajasa Raya". Jurnal Teknik Industri Vol. 3, No. 1. Teknik Industri Univ. Kristen Petra. 2001

Rizky, Putra Kusuma. "Analisis Biaya Pemeliharaan (Maintenance) Mesin pada PKS PTPN V Kebun Sei Pagar". Skripsi - Jurusan Manajemen, UIN SUSKA RIAU, Pekanbaru, 2010
Rosadi, Dadi, dkk. "Simulasi Kredit Pemasaran Mobil Bekas Berbasis WEB menggunakan Codeigniter Framework". Jurnal Computech \& Bisnis Vol. 6, No. 1. STMIK Mardira Indonesia. 2012

Sinaga, Daniel Desi. "Perencanaan Total Productive Maintenance pada Stasiun Stone Crusher (Studi Kasus: PT. Iga Bina Mix)". Tugas Akhir - Jurusan Teknik Industri, UIN SUSKA RIAU, Pekanbaru, 2016

Soesetyo, Ivan, dkk. "Penjadwalan Predictive Maintenance dan biaya Perawatan Mesin Pellet di PT. Charoen Pokphand Indonesia-Sepanjang". Jurnal Titra Vol. 2, No. 2. Univ. Kristen Petra, 2014

Wahyudi, Didik, dkk. "Analisis Perawatan Unit Pembangkit Gresik Unit III dengan Metode Reliability Centered Maintenance". Seminar Nasional VI Teknik Mesin dan Industri. UGM. 2010

Widianto, Tutur. "Analisis Kerusakan pada Mesin Large Pres $500 \mathrm{~T}$ Menggunakan Metode Overall Equipment Effectiveness (OEE) PT. Parmindo Tiga T'. Tugas Sarjana Jurusan Teknik Industri, Universitas Muhammadiyah, Surakarta, 2014

Widyaningsih, Sri Astuti. "Perancangan Penjadwalan Pemeliharaan pada Mesin Produksi Bahan Bangunan untuk Meningkatkan Kehandalan Mesin denga Metode Reliability Centered Maintenance (RCM)". Skripsi - Program Studi Teknik Industri, Universitas Indonesia, Depok, 2011 